\title{
DIAKRONIKA
}

Vol. 18 No. 1 Th. 2018 p: $33-45$

ISSN: 1411-1764 (Print) | 2620-9446 (Online)

http://diakronika.ppj.unp.ac.id

\section{Eksistensi Bima Dalam Pelayaran Dan Perdagangan Antar Pulau}

\author{
Sumiyati \\ sumimaci068@gmail.com \\ STKIP YPI Dompu
}

\begin{abstract}
Bima is a region in eastern Sumbawa Island. It has been a port town docked by many merchant ship from many region for centuries. It cannot be denied that trading activity in Bima Port is dominated by merchants from Bugis-Makassar and Malay who played up their trade widely into another island such as Flores and other eastern region, because Islamization and its closely relationship between South Sulawesi and Malay merchants. Since 16th century, Bima considered as one of the most important trade town, with the result that VOC endeavour to make a monopoly trade with ruler of Bima. The number of sailors and merchants from any direction makes Bima more crowdly. The great commodity of Bima is Kayu Sapan.
\end{abstract}

Keywords: Existence; Bima; sailing; trading; export-import

\begin{abstract}
Abstrak
Bima merupakan sebuah wilayah yang terletak di ujung timur pulau Sumbawa. Bima sejak berabad-abad lalu telah menjadi kota pelabuhan yang disinggahi oleh kapal-kapal dagang dari berbagai daerah. Namun tidak bisa dipungkiri perkembangan perdagangan dipelabuhan Bima banyak didominasi oleh pedagang dari Bugis-Makassar yang mengembangkan usaha pelayaran dan perdagangan yang lebih luas ke berbagai wilayah luar, seperti pulau Flores dan wilayah timur lainya. Bima menjadi pelaku dagang namun bukan pelayar yang aktif melainkan hanya menjadi bandar niaga.Pelayar yang aktif di pelabuhan Bima banyak didominasi oleh orang-orang Sulawesi Selatan dan Melayu. Ini tidak terlepas dari islamisasi dan hubungan antara Bima dengan pedagang Sulawesi Selatan dan Melayu yang sudah terjalin dengan baik. Sejak zaman Kompeni Bima dianggap sebagai salah satu kota perdagangan yang penting sehingga Kompeni Belanda berusaha untuk membuat perjanjian monopoli dengan penguasa Bima. Banyaknyapara pelayar dan pedagang dari berbagai penjuru datang ke Bima membuat pelabuhan Bima semakin ramai. Komoditas utama aktivitas perdagangan di Bima adalah kudan kayu sapan.
\end{abstract}

Kata Kunci: Eksistensi; Bima; pelayaran; perdagangan;ekspor-impor 


\section{Pendahuluan}

Selama berabad-abad lamanya kerajaan-kerajaan kecil yang terpencar letaknya di pulau-pulau Indonesia secara ekonomi, kultural, dan sewaktuwaktu secara politis telah tergabung atau digabungkan dalam satuan yang lebih besar. Adanya komunikasi dan lalu lintas antar pulau memungkinkan bagi penduduk mengembangkan suatu jaringan hubungan maritim yang lebih baik, didukung oleh kemajuan teknologi kapal dan keahlian navigasi. Sifat internasional dari pelayaran dan perdagangan telah nampak pula pada zaman kerajaan-kerajaan di Nusantara.

Perkembangan politik kerajaan-kerajaan yang tersebar di kepulauan Nusantara sedikit-banyaknya dipengaruhi oleh pelayaran dan perdagangan maritim. Lihat saja kerajaan-kerajaan pesisir yang memiliki tingkat perkembangan yang sangat cepat dibandingkan dengan kerajaan yang terbangun dipedalaman dan kontak budaya yang terjadi banyak dipengaruhi oleh pelayaran dan perdagangan maritim. Pemanfaatan laut sebagai transportasi dan perdagangan maritim telah menimbulkan dinamika sosial dan politik antar kekuatan politik lokal maupun asing di masa lalu. Hal ini telah dilakukan oleh kerajaan yang berada di wilayah Barat Nusantara (Kerajaan Sriwijaya, Samudera Pasai), kerajaan pesisir di Jawa (Majapahit, Demak, Banten)dan wilayah Timur Nusantara (Kerajaan Gowa-Tallo, Ternate dan Tidore) yang memfokuskan pembangunan pada sektorkemaritiman. Nusa Tenggara kemudian muncul sebagai salah satu jalur yang ramai juga dikunjungi oleh para pedagang pada masa itu.

Perkembangan perdagangan maritim mengalami kemajuan yang sangat pesat pada abad ke-15, dimana rempah-rempah menjadi komoditi utama yang paling laku di pasaran dunia khususnya Eropa. Pada masa itu Malaka berhasil menjadi pelabuhan utama bagi perdagangan rempah-rempah dan daerah transit bagi para pedagang luar maupun lokal. Tom Pires menjelaskan bagaimana Malaka memiliki jaringan perdagangan yang sangat luas. Dari hubungan dagang yang sangat luas itu, Malaka berinteraksi hampir dengan seluruh wilayah Nusantara,begitupun dengan daerah lainnya seperti pada trayek Timor dan Maluku yang kaya dengan hasil alamnya. Bahasa Melayu menjadi bahasa pemersatu dalam aktivitas perdagangan di pelabuhan Malaka. Bahasa Melayu digunakan sebagai bahasa pemersatu bangsa Indonesia sampai hari ini. Perdagangan rempah-rempah telah membuka banyak jalur pelayaran bagi perdagangan maritime. Banyak para pedagang Eropa datang ke Nusantara dan ada beberapa yang kemudian membuka jalur atau rute perjalanan baru sehingga memperluaskontak budaya dan politik antara pulau. 
Perdagangan juga merupakan media yang digunakan sebagai syiar agama baik Islam, Kristen maupun agama lainya, namun yang mengakar di Indonesia adalah agama Islam yang dibawa oleh para pedagang dari Arab, Cina, dan India.Agama Kristen dibawa oleh pedagang Portugis, Spanyol, dan Belanda terutama ditemukan di wilayah timur Indonesia, khususnya pulau NTT dan wilayah lain di Nusantara. Keberadaan agama Islam dan Kristen pada waktu itu memiliki pengaruh kuat dan kedua agama ini masih ada sampai sekarang. Keberadaan agama Islam dan Kristen pada waktu itu juga banyak memberi pengaruh pada budaya masyarakat setempat. Perkembangan pengaruh Islam di Indonesia tidak terlepas dari pengaruh politik yang ada di luar Nusantara seperti kejayaan Turki Otoman yang pada tahun 1453 berhasil menaklukkan kota Kostantinopel (Riclefis, 2007). Pada zaman kerajaam Islam, jalur perdagangan antar Pulau di Nusantara menjadi bagian yang inheren dalam konteks perdagangan internasional.

Perdagangan maritim sangat penting sebagai media integrasi baik secara politik maupun ekonomi, dan ini sangat disadari sepenuhnya oleh kolonial Belanda, yang kemudian pada abad ke-17 hingga abad ke-19, kebijakan politik lebih difokuskan pada perdagangan maritim, terutama dari dan ke pulau Maluku yang merupakan daerah asal rempah-rempah. Kemudian ditegaskan dengan dioperasikannya Koninklije Pakervaart Maatschappij (KPM) pada tahun 1891, yang difokuskan khusus pada integrasi ekonomi dan politik Nusantara di bawah payung politik Hindia Belanda (ABD, 2010).

\section{Pembahasan}

Bima merupakan sebuah wilayah yang terletak di ujung timur pulau Sumbawa. Bima sejak berabad-abad lalu telah menjadi sebuah wilayah yang selalu disinggahi oleh kapal-kapal dagang dari berbagai wilayah. Bima memiliki sebuah teluk yang cukup lebar dan dalam, sehingga kapal-kapal dagang bisa berlayar dan masuk ke pelabuhan Bima. Pelabuhan Bima sejak berabad-abad lalu telah banyak disinggahi oleh kapal dagang bangsa-bangsa barat dan membentuk rute pelayaran dan perdagangan dari Barat, begitupun sebaliknya.

Bima menjadi tempat untuk mengisi perbekalan karena Bima memiliki banyak bahan makanan, di samping komoditi perdagangan. Bima menjadi wilayah yang penting dalam dunia pelayaran. Pada abad ke-16 menurut laporan Tome Pires produk-produk perdagangan dari Bima dan Sumbawa antara lain; kuda, budak, daging, kayu sapan dan tekstil. Dikatakan pula bahwa kota-kota pelabuhan di pulau Sumbawa seperti Bima danKore di pantai utara dan Sape di pantai timur sudah berperan dalam lalu lintas perdagangan, bahkan pelabuhan Bima boleh dikatakan sudah sederajat 
dengan pelabuhan di Ternate, Makassar, Demak, Cirebon, Banten, Sunda Kelapa, Aceh dan Malaka. Bima sudah banyak dikunjungi pedagang dari Jawa, Madura, Sumatera, Bali, Selebes, Selayar, Buton, Manggarai dan Maluku bahkan Malaka,(Salahuddin. Sitti Maryam.R, 1992), pedagang dari bagian barat banyak membawa kain, pisau, pedang, tembikar Cina, timah hitam, air raksa dan manik-manik berwarna. (Lapian, 2008).

Pada musim angin barat kapal dari Gresik dan wilayah barat lainnya akan berlayar ke Nusa Tenggara. Kapal dari Malaka datang ke Nusa Tenggara untuk mengambil budak yang diperoleh di pelabuhan di Nusa Tenggara, sedangkan kuda dan kayu merah diperoleh dipelabuhan Bima, kayu cendana di wilayah Timor. Bima menjadi wilayah yang penting untuk disinggahi karena Bima merupakan salah satu pusat perniagaan dalam lalulintas pelayaran di kawasan laut selatan. Bima memiliki banyak komoditi perdagangan seperti; asam, kayu sapan, daging, ikan,dankain tenun yang diangkut dengan menggunakan perahu, dijual ke Malaka dan kemudian dikirim ke Tiongkok. Komoditas ekspor utama Bima sebelum tahun 1815 adalah beras, madu atau lilin lebah, sarang burung, kuda, garam, kapas, dan kayu sapan (Boers, 2012). Selain memiliki komoditi diekspor, Bima menerima barang yang diimpor dari daerah asing seperti kain sutera, benang-benang Eropa, barang-barang dari tanah, besi dan tembaga, barang-barang kelontong, minuman arak dan brendi, candu, gambir, rotan, senapan mesiu, timah, uang logam Cina, gula, cokelat, dan sirup (Salahuddin. Sitti Maryam.R, 1992).

Abad ke-16 perkembangan pelayaran dan perdagangan antar pulau semakin berkembang sehingga terbangun hubungan baik di bidang politik maupun ekonomi antar berbagai wilayah satu samalain. Bima menjalin hubungan politik dan hubungan ekonomi yang baik dengan Gowa-Tallo dalam perdagangan antar pulau. Pada tahun 1756 ditemukan banyak pedagang pribumi dari makassar berlayar ke Flores.Mereka berangkat pada bulan Februari sampai Maret setiap tahun sambil membawa porselin, ikan mas, gading gajah dan barang-barang dari tembaga, sebaliknya mereka berlayar kembali ke Makassar pada musim angin tenggara pada bulan Agustus - September dengan membawa barang-barang seperti sarang burung, karet, barang anyaman dan budak (Salahuddin. Sitti Maryam.R, 1992).

Sebelum abad ke-17 tidak ada informasi terperinci tentang ekspor Bima. Antara tahun 1624 dan 1665 Daghregister mencatat berulang kali tentang kedatangan produk yang dibeli dari Bima dan dibawa ke Batavia. Komoditi utama yang paling terkenal adalah beras, budak, kayu sapan (yang menghasilkan warna merah), lilin, kayu cendana, asam, sulfur, kayu manis dan gula kelapa. Komoditi dagang ini khususnya menghubungkan Bima dengan Ambon, Banjar, Makassar, Banten, Palembang dan bahkan Cina. 
Komoditi ekspor yang penting sebelumadanya islamisasi adalah daging babi. Orang Belanda membeli daging babi di Bima pada tahun 1619, di tahun ini pula terjadi serangan dari Makassar yang menandakan mulai masuknya islamisasi ke daerah ini. (Chambert -Loir, 1993).

Sebelum abad ke-19 kelompok penduduk di Nusa Tenggara sebenarnya telah membina hubungan dengan kekuatan-kekuatan diluarnya baik dalam bidang politik maupun perdagangan. Hal itu tampak pada kerajaan-kerajaan di Lombok (hubungan dengan Bali), Sumbawa-Bima dengan Gowa (Makassar) dan lingkungan Timor (khususnya Solor) pernah terkait dengan Maluku (Ternate) walaupun akhirnya di wilayah inisangat terkait dengan kekuatan Eropa terutama Portugis dan Belanda (Parimartha, 2002). Dapat dikatakan bahwa Nusa Tenggara merupakan tempat persinggahan penting dalam rangka perdagangan antara Malaka atau Indonesia bagian barat dengan Maluku atau Indonesia bagian timur, terutama Solor dan Bima di bagian utara dan Kupang, ataupundi bagian selatan. Bima juga merupakan pelabuhan dagang yang penting pada masa itu, karena antara Bima dan Solor merupakan jalur yang menuju daerah penghasil kayu cendana, pulau Sumba, Timor dan Maluku penghasil rempah-rempah.

Salah satu komoditas yang ramai diperdagangkan di Nusa Tenggara adalah Budak. Budak pada zaman itumenjadi kekayaan yang penting artinya untuk membantu tuannya bekerja di perusahaan-perusahaan perkebunan. Mereka dapat dijual, ditukar atau diperdagangkan layaknya barang dagangan lain. Aktivitas perdagangan budak sudah ada sebelum abad ke-17. Tahun 1769 Sultan Bima, Abdul Kadim mengunjungi wilayah Manggarai, setelah kembali pulang ia juga membawa hadiah budak dari tawanan perang yang terjadi di daerah Pota. Sultan Abdul Kadim juga meminta upeti hamba dari Manggarai atas desakan Kompeni Belanda, dasar hukum upeti hamba atau upeti budak ini terkenal dengan sebutan "teki mendi" (upeti berupa bayaran budak). Neraca komoditas upeti budak atau pengeksporan budak dariManggarai menurut catatan mencapai 2.000 budak pertahun termasuk sejumlah 300 hingga 400-an orang budak atas nama upeti (Nuryahman, n.d.). Budak-budak tersebut kemudian diperdagangkan melalui pelabuhan Bima.

Nusa Tenggara khususnya Bima merupakan wilayah yang banyak disinggahi oleh kapal-kapal dagang yang berlayar ke timur dan sebaliknya, namun tidak bisa dipungkiri perkembangan perdagangan di pelabuhan Bima banyak didominasi oleh pedagang dari Sulawesi selatan yangmengembangkan usaha pelayaran dan perdagangan yang lebih luas ke berbagai wilayah luar, seperti pulau Flores dan wilayah timur lainya. Bima menjadi pelaku dagang, namun bukan pelayar yang aktif melainkan hanya menjadi bandar niaga dan Bima menentukan pemungutan pajak dan bea cukai bagi kapal dan barang 
yang berniaga di pelabuhan Bima. Pelayar yang aktif di pelabuhan Bima banyak didominasi oleh orang-orang Sulawesi Selatan dan Melayu.Ini tidak terlepas dari islamisasi dan hubungan antara Bima dengan Pedagang Sulawesi Selatan dan Melayu sangat akrab.

Pelayaran dan perdagangan yang membentuk hubungan antara Bima dengan Maluku secara langsung tidak memiliki banyak data dan catatan sejarah melainkan, Bima dengan Maluku lebih banyak dihubungkan oleh para pedagang dari wilayah barat terutama pedagang Jawa dan Sumatera dimana para pedagang dari Jawa membeli kain kasar untuk ditukar degan rempahrempah di Maluku. Maluku dengan Bima juga lebih banyak dihubungkan oleh pedagang Makassar dengan adanya perdagangan beras. Makassar menyuplai beras ke Maluku yang sebagian diambil dari Bima begitupun barang lainnya, Bima mengekspornya melalui pelabuhan Makassar.

Dengan wilayah timur lainnya seperti pulau Flores dan Timor, Bima mengirim perahu untuk mengangkut barang-barang dagangan. Tidak banyak data dan informasi sejarah yang menyebutkan barang-barang dagangan yang dibawa ke timur, namun yang dijelaskan hanya Bima mengambil sejumlah barang dagangan di timur terutama Manggarai, Sumba dan Solor yang merupakan daerah di bawah kekuasaan Bima dan harus membayar Upeti ke Bima.

Pelayaran dan perdagangan sebelum abad ke-19 dimonopoli oleh kompeni Belanda dimana pelabuhan-pelabuhan penting dan jalur pelayaran dikuasaihingga dibukapelabuhan bebas Singapura pada tahun 1819 yang membuat pelabuhan-pelabuhan yang berada di kepulauan Nusantara menjadi semakin ramai.Sejak zaman Kompeni, Bima dianggap sebagai salah satu kota perdagangan yang penting sehingga Kompeni selalu berusaha untuk membuat perjanjian monopoli dengan penguasa Bima. Pada tahun 1669 Sultan Bima membuat perjanjian dengan Admiral Speelman (naskah 5).Hal yang dipertegas dalam perjanjian itu adalah keinginan agar hanya Kompeni Belanda yang boleh berdagang di tanah Bima, sementara pihak Bima tidak boleh memasukan pedagang lain tanpa seizin Kompeni Belanda.Selain itu yang termasuk dalam perjanjian itu adalah Kompeni Belanda dibebaskan dari pajak dan bea cukai (Salahuddin. Sitti Maryam.R, 2004).

Abad ke-19 pelayaran dan perdagangan berkembang semakin maju dan tumbuh pesat.Para pedagang dari Eropa semakin membanjiri Asia sebab pada masa ini berkembang perdagangan hasil industri dari Eropa. Kondisi ini membuat banyak pusat-pusat niaga yang tumbuh dan berkembang seperti pulau Pinang, Singapura, Pahang, dan Hongkong. Dari perkembangan ini dunia pelayaran memunculkan wajah baru dengan peralihan dari kapal layar ke kapal api(uap). 
Perkembangan kapal uap membawa pengaruh dan perubahan besar terhadap dunia pelayaran dimana arah pelayaran yang dulunya memiliki kecenderungan untuk singgah-singgah dari satu pelabuhan ke pelabuhan berikutnya, kemudian bisa dilakukan melalui pelayaran langsung ke daerah tujuan. Perkembangan ini membuat aktivitas pelayaran menjadi lebih terstruktur karena tidak lagi mengandalkan arah angina, bahkan mengharuskan para pedagang menunggu perubahan musim dan arah angin yang sesuai untuk kemudian baru melakukan pelayaran. Kondisi seperti ini membuat distribusi barang dagangan dan lainnya menjadi tidak menentu.

Peristiwa Tambora membuat kehidupan masyarakat di wilayah Sumbawa pada umumnya dalam kesulitan yang tidak terhingga. Seperti yang telah dijelaskan pada penjelasan sebelumnya dalam berbagai sumber selama rentan waktu peristiwa tersebut tahun 1815 sampai 15 tahun kemudian kehidupan masyarakat Bima dalam kondisi yang sangat sulit, namun setelah kunjungan Zollinger tahun 1847 mengatakan bahwamasyarakat yang ada di Kerajaan Bima mulai bisa menata kembali kehidupan mereka. Masyarakat melakukan produksi garam dan kemudian diekspor ke Selayar dan beberapa daerah di Sulawesi.

Kondisi yang baik setelah peristiwa Tambora mulai dirasakan setelah tahun 1829 dimana tanah pertanian mulai bisa digarap kembali dan menunjukan kesuburan yang cukup baik bagi komoditi pertanian yang ditanam. Beberapa komoditi dagang yang diperjual-belikan di pelabuhan Bima mulai tahun 1829, terdiri dari hasil hutan, hasil pertanian dan hasil peternakan. Di samping itu juga ada beberapa hasil karya rumah tangga berupakain tenun, parang-parang, dan teripang walaupun tidak dalam jumlah besar.

Pada tahun 1840 Bima mengekspor beberapa hasil pertanian seperti beras, kacang ijo dan hasil laut terutama teripang (Parimartha, 2002). Perdagangan semakin ramai dengan dibukanya pelabuhan Singapura, jalur pelayaran semakin ramai dan Bima termasuk wilayah yang ramai dikunjungi karena kebutuhan kayu sapan dan cendana yang berasal dari Timor diperdagangkan melalui pelabuhan Bima. Dibukanya pelabuhan bebas Singapura membuat komunitas Cina semakin berkembang di wilayah kepulauan dan pada saat itu kuda menjadi salah satu komuditi dagang yang baru (Parimartha, 2002).

Dari tahun ke tahun kegiatan ekspor-impor yang terjadi dipelabuhan Bima semakin menunjukan aktifitas yang ramai. Banyaknyapara pelayar dan pedagang dari berbagai penjuru tertarik datang ke Bima telah menjadikan pelabuhan Bima semakin ramai dan kemudian banyak komunitas yang mendiami Bima dalam waktu yang lama sehingga tidak mengherankan 
terjadinya percampuran masyarakat melalui kawin mawin antara para pedagang dengan penduduk asli. Kenyataan ini pada akhirnya semakin memperkaya khasanah budaya daerah ini.

Tahun 1848 sultan Bima mengatur sepenuhnya perkembangan perdagangan serta membatasi usaha Belanda dalam memonopoli perdagangan. Sultan Bima mengatur sendiri segala bentuk aktifitas niaga di pelabuhan Bima termasuk menjadikannya sebagai pelabuhan bebas bagi para pedagang Melayu, Bugis-Makssar, serta pedagang pribumi lainya. Sultan Bima menetapkan pajak yang tidak memberatkansehingga mampu membuat pelabuhan Bima menjadi lebih tertib. Raja mengangkat seorang yang bertugas khusus untuk menangani persoalan perniagaan yang disebut sebagai Syahbandar. Dalam aktivitas perdagangan kesultanan Bima memberikan kebebasan bagi para pedagang Bugis-Makassar untuk berniaga di wilayahnya dan bahkan diizinkan membentuk perkampungan-perkampungan Bugis di wilayah kesultanan Bima. Sampai hari ini masih bisa ditemukan keberadaan perkampunga Bugis yang banyak berada di wilayah pesisir pantai yang disebut dengan kampung Bugis.

Di samping itu Kolonial Belanda telah melakukan monopoli perdagangan di banyak tempat mengambil peran juga dalam perdagangan di pelabuhankesultanan Bima. Dengan berbagai macam cara kolonial Belanda melakukan blokade terhadap pelabuhan Bima dan beberapa komoditi dagang yang merupakan hasil alam kesultanan Bima dengan melakukan kontrak dagang. Aktifitas dagang yang terbangun di Pulau Sumbawa banyak didominasi oleh padagang-pedagang luar (asing). Sejauh ini data yang menunjukan peran aktif pedagang lokal atau penduduk setempat dalam aktifitas dagang antar pulau hanya sedikit.Orang-orang pribumi yang ikut dalam perdagangan antar pulau banyak dilakukan oleh para petinggi kerajaan atau para bangsawan dan tidak serta merta mengatakan bahwa penduduk lokal tidak memiliki peran dalam hal ini.

Pulau Sumbawa adalah wilayah yang kaya akan hasil alam, hasil pertanian dan peternakan untuk diekspor ke luar wilayah pulau Sumbawa dalam jumlah banyak. Sebuah kerajaan kecil diujung timur pulau Sumbawa, Bima merupakan wilayah kerajaan yang mengembangkan sektor pertanian untuk menunjang perdagangan antar pulau di wilayahnya. Permintaan akan komoditi beras dalam perdagangan antar pulau telah mendorong pembukaan sektor pertanian yang terus berkembang. Bima sendiri memiliki kekayaan alam yang cukup banyak sebagai daerah produsen bagi perdagangan antar pulau. Bima menjadi daerah transit bagi pelayaran baik dari arah barat ke timur maupun yang berasal dari utara ke selatan. Tingkat keramaian aktivitas pelayaran dan perdagangan semakin menunjukkan pola yang 
kompleksmengindikasikan perkembangan perdagangan di Bima menjadi semakin maju. Banyak kemudian para pedagang dan pendatang mendominasi karena diberikan kebebasan oleh penguasa lokal untuk mengembangkan usahanya seperti pedagang Bugis, Makassar, Melayu, Jawa, Bali, Arab, Cina.

Pedagang Melayu dan Bugis-Makassar mendominasi pola pelayaran dan perdagangan di Bima. Sejak tahun 1848 pelabuhan Bima menjadi pelabuhan bebas bagi pedagang Bugis-Makassar, Melayu dan juga pedagang pribumi lainya. Di Bima para pedagang pribumi (Melayu, Bugis dan Makassar) dibebaskan dari pajak yang memberatkan dalam hal ini kontrak dengan Kompeni Belanda diabaikan oleh penguasa lokal Bima sehingga tidak berarti apa-apa (Parimartha, 2002).

Kerajaan Bima menjadi wilayah yang ramai dikunjungi oleh para pedagang baik pedagang lokal dalam arti pedagang Nusantara maupun para pedagang dari wilayah Eropa dan bangsa Asia lainya. Salah satu faktor pendukungnya karena Bima memiliki komoditi yang pantas untuk diperdagangkan. Wilayah kerajaan Bima banyak terdiri dari gunung-gunung dan hamparan padang rumput yang luas serta memiliki hasil alam yang laku diperdagangkan. Kayu sapan menjadi komoditi utama daerah ini sebelum dimonopoli oleh Belanda, di samping hasil peternakan seperti kuda, sapi, kerbau dan hewan lainya. Bima merupakan daerah penghasil kuda terbaik yang ada di Nusantara pada masa itu.

Pembukaan pelabuhan bebas Singapura ditandai dengan berkembangnya perdagangan kuda. Kuda dari Bima terkenal dengan kuda yang paling kuat dan mampu menjadi hewan pengangkut yang baik. Kuda merupakan hasil peternakan pribadi raja dan para petinggi kerajaan lainnya. Kuda dipelihara dalam jumlah besar yang digembalakan oleh budak. Perdagangan kuda di Bima banyak dikuasai oleh pedagang Arab. Tidak banyak data sejarah yang menjelaskan secara detail mengenai kuda yang diekspor keluar setiap tahunya, melainkan hanya beberapa data yang menjelaskan tahun yang tidak berurutan (Parimartha, 2002). Tahun 1820 kuda diekspor sebanyak 100 ekor, tahun 1829 sebanyak 253, tahun 1833 sebanyak 229, tahun 1845 dan 1846 masing-masing 948 dan 872 ekor. Berdasarkan laporan Freijss (1854) menyebutkan bahwa Bima mengekspor kuda sebanyak 300 ekor setiap tahunya.

Komoditiperdagangan lain yang paling terkenal di pelabuhan Bima abad ke-19 adalah kayu sapan yang dalam bahasa daerah Bima disebuthaju supa. Kayu sapan sangat diminati dan dicari karena memiliki banyak kegunaan serta sifat terbaik dari kayu ini adalah kekerasan dan ketahanannya. Bahkan ketika terkena air dalam waktu lama, kayunya tidak membusuk. Karena itu kayu sapan sangat terkenal cocok untuk dijadikan bahan pembuatan kapal. 
Sedangkan untuk keperluan industri, penggunaan utama kayu sapan adalah untuk membuat paku dan peniti kayu. Tiang layar juga dibuat dari batang sapan. Di luar pembangunan kapal, kayu ini digunakan untuk membangun perabotan, bingkai dan jendela. Karena kekerasannya, kayu ini juga cocok untuk membuat tongkat berjalan (Boomgaard, Henley, \& Henley, 1997).

Kegunaan lain dari kayu sapan adalah untuk membuat cat merah, dimana warna merah yang diinginkan akan didapatkan dengan cara merendam kayu sapan pada air yang digunakan untuk mewarnai kain dan kue. Di Eropa kayu sapan digunakan sebagai cat. Kayu sapan dihancurkan terlebih dahulu sebelum diproses menjadi cat. Sementara di Cina cat sapan digunakan untuk mewarnai kertas tanpa menambahkan daun tertentu, dan warna bisa dibuat lebih muda atau lebih cerah. Karena unsur warna yang berguna, pohon sapan menjadi komoditi dagang yang terkenal di masa lalu dan menjadi salah satu primadona sampai awal abad ke-20 (Boomgaard et al., 1997). Kayu sapan sejak abad ke-18 telah menjadi primadona dalam perdagangan karena memiliki banyak kegunaan. Makassar menggunakan kayu sapan sebagai bahan utama dalam pembuatan kapal (Boomgaard et al., 1997). Kayu sapan sebelum dimonopoli oleh Belanda, orang Portugis telah lebih dulu mengambil keuntungan pada penjualan kayu sapan. Ekspor kayu sapan selalu tidak menentu, selain faktor kekurangan tenaga yang mengambil kayu tersebut dihutan juga karena keterbatasan alat dan perlengkapan untuk menebang kayu.

\section{Simpulan}

Kesultanan Bima merupakan salah satu kesultanan yang menjadi wilayah perniagaan. Perekembangan Kesultanan Bima menjadi sebuah wilayah niaga bukan karena masyarakatnya yang dominan para pelaut melainkan posisi atau letak geografis Bima yang cukup strategis. Sejak berabad-abad lamanya Bima telah menjadi daerah yang cukup ramai dikunjungi hingga muncul intervensi Kolonial Belanda melalui kontrak 1667. Belanda berusaha menguasai Bima dengan kontrak Kayu Sapan yang harus diserahkan kepada Belanda. Letak geografis yang didukung dengan hasil alam yang memadai membuat Bima semakin ramai dikunjungi. Kayu sapan yang laku di pasaran sebagai bahan utama pembuatan cat dengan warna merah alami semakin menguatkan Bima sebagai wilayah niaga, dan tentu saja mendorong keinginan para pedagang untuk mendapatkan kayu Cendana di Timor dan Bima merupakan pintu masuk kearah timur. Penguasaan pelabuhan Makassar oleh Kolonial Belanda membuat banyak pelayar dan pedagang pribumi mencari daerah prerniagaan baru sekaligus menciptakan jalur pelayaran baru. Walaupun Bima telah muncul sejak lama sebagai 
wilayah perniagaan, Bima juga menjadi tujuan utama pelayaran dengan semakin aktifnya para pelayar dan pedagang Bugis-Makassar dan Melayu berdatangan di wilayah tersebut.

\section{Daftar Rujukan}

Ardhana, I. K. (2005). Penataan Nusa Tenggara pada masa kolonial 1915 1950. Jakarta: Raja Grafindo Persada.

Arsyad. Armin. (n.d.). politik maritim dan perdagangan di Bandar Makassar.

BOERS, B. D. (1994). TAMBORA 1815-THE HISTORY OF A VOLCANICERUPTION IN INDONESIA. TIJDSCHRIFT VOOR GESCHIEDENIS, 1073), 371-392.

Boers, B. D. J. (2012). MOUNT TAMBORA IN 1815: A VOLCANIC ERUPTION IN INDONESIA AND ITS AFTERMATH. 107(July), 2.

Boomgaard, P., Henley, D., \& Henley, D. (1997). Explorations in the environmental history of Indonesia Edited by. Leiden: KITLV Press Leiden.

Burhanuddin, S. (2003). Sejarah Maritim. In Sejarah Maritim Indonesia (Vol. 185). Jakarta: Pusat Kajian Sejarah dan Budaya Maritim Asia Tenggara.

Chambert-Loir, H. (2004). Kerajaan Bima dalam sastra dan sejarah. Jakarta: EFEO Kepustakaan Populer Gramedia.

Chambert-Loir, H. (2010). dkk. Iman dan Diplomasi: Serpihan Sejarah Kerajaan Bima. Jakarta: EFEO Kepustakaan Populer Gramedia.

Chambert-Loir, H., \& Salahuddin, M. R. (2000). Bo Sangaji Kai Catatan Kerajaan Bima, Jakarta: Yayasan Obor Indonesia. Jakarta: EFEO Kepustakaan Populer Gramedia.

Chambert -Loir, H. (1993). State, City, Commerce: The Caseof Bima. Indonesia, 57, 71-88.

Hamid. Abd. Rahman. (2008). Spirit Bahari Orang Buton. Makassar: Rayhan Intermedia.

Ismail, M. H. (2004). Peran Kesultanan Bima dalam Perjalanan Sejarah Nusantara. Mataram: Lengge bekerjasama dengan Yayasan Adikarya IKAPI dan the Ford Foundation.

Ismail, M. H. (2006). Sejarah Mbojo Bima. Bogor: CV BINASTI.

Jong Boers, Bernice de, H. S. (2012). Letusan Gunung Tambora 1815. Yogyakarta: Ombak.

Jong Boers, B. de. (1997). Kemampuan Bertahandan Perspektif Waktu dalamManajemen Pengolahan Sumber Daya Alam: Eksploitasi pohon sappan di hutan-hutan Sumbawa, Indonesia 1500-1875. Sumber: Peter 
Boomgaard, Freek Colombijn and David Henley, Paper Landscapes: Explorations in the enviro. Leiden: KITLV Press.

Lapian, A. B. (1996). Peta Pelayaran Nusantara dari Masa ke Masa. JATIJOURNAL OF SOUTHEAST ASIAN STUDIES, 2, 35-52.

Lapian, A. B. (2008). Pelayaran dan perdagangan Nusantara abad ke-16 dan 17. Jakarta: Komunitas Bambu.

Lapian, A. B. (2009). Orang laut, bajak laut, raja laut: sejarah kawasan Laut Sulawesi abad XIX. Jakarta: Komunitas Bambu.

Lombard, D. (2008). Nusa Jawa: Silang Budaya, Bagian III: Warisan KerajaanKerajaan Konsentris (Diterjemahkan oleh Winarsih Partaningrat Arifin dkk). Jakarta: PT Gramedia Pustaka Utama.

Noorduyn, J. (2007). Sejarah Sumbawa (Diterjemahkan oleh Muslimin Jasin). Yogyakarta: Riset Informasi dan Arsip Kenegaraan.

Nuryahman. (n.d.). Perdagangan Budak di Nusa Tenggara sampai pada Abad ke-19. Balai Kajian Sejarah dan Nilai Tradisional Bali, NTB, NTT.

Parimartha, I. G. (2002). Perdagangan dan Politik di Nusa Tenggara 18151915. In Perdagangan dan politik di Nusa Tenggara 1815-1915. Jakarta: Djambatan.

Poelinggomang, E. L. (n.d.). Indonesia Negara Kepulauan atau Negara Laut.

Poelinggomang, E. L. (2003). Pelayaran dan Perdagangan Maritim Masyarakat Sulawesi Selatan. Di sampaikan pada seminar Sejarah dan Budaya Maritim Sulawesi Selatan.

Poelinggomang, E. L. (2016). Makassar abad XIX: Studi Tentang Kebijakan Perdagangan Maritim. Jakarta: Kepustakaan Populer Gramedia.

Salahuddin. Sitti Maryam.R. (1992). Bandar Bima. Jakarta: Depdikbud.

Salahuddin. Sitti Maryam.R. (2004). Undang- Undang Bandar Bima. Mataram: Lengge.

Tajib, A. B. . (1995). Sejarah Bima Dana Mbojo. Jakarta: PT. HarapanMasa PGR.

Tobing, P. (1967). Hukum Pelayaran dan Perniagaan Amanna Gappa. Ujung Pandang: Yayasan Kebudayaan Sulawesi.

Zollinger, H. (1851). Verslag van eene reis naar Bima en Soembawa, en naar eenige plaatsen op Celebes, Saleijer en Floris, gedurende de maanden Mei tot December 1847. Batavia: Bataviaasch Genootschap van Kunsten en Wetenschappen, Lange. 